\title{
Separation/divorce sexual assault: The current state of social scientific knowledge
}

\author{
Walter S. DeKeseredy*, McKenzie Rogness, Martin D. Schwartz \\ Department of Sociology and Anthropology, Ohio University, Athens, OH 45701, USA
}

Received 10 February 2003; received in revised form 24 July 2003; accepted 11 August 2003

\begin{abstract}
Many contend that the logical solution to woman abuse in marriage/cohabitation is for women to exit through legal separation, divorce, or other means. However, a growing body of empirical work shows that separation or divorce does not necessarily solve the problem of woman abuse. For example, in addition to experiencing lethal or nonlethal forms of physical violence and psychological abuse, many women who try to leave, or who have left their male partners, are sexually assaulted. The main objective of this paper is to critically review the extant empirical and theoretical work on separation/ divorce sexual assault. Suggestions for future research and theorizing are also provided.
\end{abstract}

(C) 2003 Elsevier Ltd. All rights reserved.

Keywords: Sexual assault; Separation; Divorce; Women; Research; Theory

\section{Introduction}

Much of the existing research on intimate male violence against women has focused on the prevalence of and response to abuse that occurs within an ongoing intimate relationship. Little attention has been paid to the abuse that occurs after women have ended relationships (Fleury, Sullivan, \& Bybee, 2000, p. 1363).

\footnotetext{
* Corresponding author. Tel.: +1-740-594-8765; fax: +1-740-593-1365.

E-mail addresses: dekesere@ohiou.edu (W.S. DeKeseredy), m_rogness@hotmail.com (M. Rogness), schwartz@ohio.edu (M.D. Schwartz).

1359-1789/\$ - see front matter (C) 2003 Elsevier Ltd. All rights reserved. doi:10.1016/j.avb.2003.08.004
} 
In what is actually an understatement, Renzetti, Edleson and Bergen (2001, p. 1) remind us in the Sourcebook on Violence Against Women, "In only about three decades, research and writing about violence against women has mushroomed." Even leading experts in the field argue that "keeping up" with the rapidly growing body of social scientific knowledge on the many intentional male-perpetrated harms women endure in intimate heterosexual relationships is an overwhelming and constantly ongoing task. This is because scores of social scientists have not only produced rich data on the extent, distribution, correlates, and outcomes of a broad range of highly injurious male-to-female assaults in a variety of relationships and social settings, but they have also constructed and tested many competing theories. ${ }^{1}$ However, some abused women have received much more attention than others. For example, the empirical and theoretical work done so far in the United States focuses mainly on male-to-female psychological, sexual, and physical assaults in dating and marriage/ cohabitation (Fleury et al., 2000). Clearly, the women victimized in these ongoing relationships "do not represent the entire spectrum of abused women" (Sev'er, 2002, p. 12).

Consider those who want to end, are planning to end, trying to end, in the process of ending, or who have ended a relationship with a marital/cohabiting partner. Only a few North American studies have focused on women who are trying to leave or who have left "the house of horrors" (Sev'er, 2002), and all of them show that separation/divorce can result in homicide or major violence-inflicted injuries. For example, in $16 \%$ of the cases of intimate femicide $^{2}(N=705)$ that occurred in Ontario, Canada, between 1974 and 1994, the victims were separated from their legal spouses (Gartner, Dawson, \& Crawford, 2001). Furthermore, throughout Canada, Wilson and Daly (1994) found that compared to coresiding couples, separation entails a sixfold increase in homicide risk for women. U.S. research also shows that separation is a key risk factor of femicide. ${ }^{3}$

If separation/divorce is a major determinant of intimate femicide, the same can be said about nonlethal violence against women (e.g., violent acts that do not result in death). For example, U.S. researchers Fleury et al. (2000) found that more than one third $(36 \%, n=49)$ of the women $(N=135)$ who participated in their longitudinal study were assaulted by a male ex-partner during a 2 -year period. Moreover, $40 \%$ of the 75 divorced men who participated in Arendell's (1995) study stated that they threatened or used violence against their former spouses after separation. Note, too, that data generated by the redesigned National Crime Victimization Survey reveal that separated women were assaulted three times more often than divorced women and close to 25 times more than married women (Bachman \& Saltzman, 1995).

Nonlethal separation assault is also common in Canada. Statistics Canada's national Violence Against Women Survey found that about one fifth (19\%) of the women who reported violence by a previous male partner stated that the violence increased in severity at the time of separation (Johnson \& Sacco, 1995; Rodgers, 1994). Several other North

\footnotetext{
${ }^{1}$ See DeKeseredy and MacLeod (1997) and Jasinski (2001) for comprehensive reviews of the theoretical literature on woman abuse.

${ }^{2}$ Intimate femicide is defined here as "the killing of females by male partners with whom they have, have had, or want to have, a sexual and/or emotional relationship" (Ellis and DeKeseredy, 1997, p. 592).

${ }^{3}$ See Hardesty (2002) for an in-depth review of the empirical literature on "lethal separation assault."
} 
American studies, most of which are Canadian, uncovered similar data, with the risk of assault peaking in the first 2 months following separation and when women attempt permanent separation through legal or other means (Ellis, 1992).

Based on the small amount of literature summarized here and elsewhere (e.g., Hardesty, 2002), we can conclude, then, that the risks of nonlethal violence and intimate femicide are highest when women seek freedom from their abusive spouses or other men they have been living with in an intimate relationship (Ellis \& Stuckless, 1996; Pagelow, 1993). Nevertheless, abuse, regardless of whether women are in ongoing relationships, are trying to end them, or have ended them, is "multidimensional in nature" (DeKeseredy \& Hinch, 1991). Specifically, in addition to experiencing lethal or nonlethal forms of physical violence and psychological abuse, many women who try to leave or who have left their partners are sexually assaulted. For example, Fleury et al. (2000) found that of the 49 women in their sample who were assaulted by an ex-partner, $20 \%$ were raped. There are, of course, other types of sexual assaults that many other women may have suffered. However, we do not know for sure because social scientists have devoted very little attention to separation/divorce sexual assault. Thus, a major research gap needs to be filled.

Why has the sexual abuse of women by their former spouses or cohabiting partners received "selective inattention" (Dexter, 1958)? It is beyond the scope of this paper to answer this important question. Rather, our main objective is to critically review the limited social scientific contributions that have been made and to provide suggestions for future research and theorizing. It is to the extant empirical work that we now turn.

\section{Research on separation/divorce sexual assault}

Before reviewing the limited empirical work on separation/divorce sexual assault, it is first necessary to address how social scientists have defined this problem because definitions determine the research methods they use, as well as the theoretical framework that drives the collection and analysis of their data (Ellis, 1987). Again, harmful sexual acts that occur during and after the stages of separation/divorce have received short shrift and most of the information that is available on these harms is found in the small amount of feminist literature on what is variously termed marital rape, spousal rape, wife rape, or sexual assault in marriage.

\subsection{Definitions}

Excluded from some prominent studies that use one of the above or similar terms are cohabitors or live-in lovers. Consider Russell's (1990) groundbreaking representative sample survey that was conducted in San Francisco. Only a few common-law relationships were included in her analysis when respondents made explicit that they viewed their partners as husbands. ${ }^{4}$ Excluding current or former live-in lovers from definitions of separation/divorce

\footnotetext{
${ }^{4}$ Peacock's (1998) work is another example of a marital rape study that excluded cohabitors.
} 
sexual assault is problematic for several reasons. For example, a woman does not have to be legally tied to a man to experience the pain and suffering caused by sexual assault (Bergen, 1996). Indeed, national representative sample survey data show that many women are sexually abused by their common-law partners, and male cohabitors are more likely to sexually abuse their partners than those in casual or serious dating relationships (DeKeseredy and Schwartz, 1998). Furthermore, as Campbell (1989, p. 336) points out, "a marriage license probably does not change the dynamics of sexual abuse within an ongoing intimate relationship...." Moreover, cohabiting men are more likely to beat their wives than are married men (Ellis \& DeKeseredy, 1989; Kennedy \& Dutton, 1989; Smith, 1990a).

Thus, it is fair to assume that male cohabitors may be at higher risk of being sexually abusive than married men and this risk probably increases when their partners try to leave or do leave them. To the best of our knowledge, only Finkelhor and Yllo's (1985) Boston survey tested this hypothesis. Their data described in Table 1 support it and the assertion that legally separated/divorced women are at higher risk than married women. Unfortunately, their survey excluded women who did not have children between the ages of 6 and 14 living with them. If such women did participate, chances are that the rates of sexual assault against women who ended their relationships with spouses/cohabitors would be higher.

Based on the data described in Table 1 and other factors, we contend that definitions of separation/divorce as used in sexual assault research require the inclusion of cohabiting couples, as well as common-law relationships that are in the process of ending or that have ended. However, when conducting a survey, simply identifying through statistical means that women who are separated from their spouses or cohabiting partners report higher rates of sexual assault does not tell us whether abuse caused estrangement or if abuse started during or after breakups (Statistics Canada, 1990). Still, the relationship between separation/divorce and sexual violence identified by Finkelhor and Yllo (1985) is "more than coincidental" (Hardesty, 2002).

A more recent and much larger study - the U.S. National Violence Against Women Survey (VAWS) - also tested the hypothesis that sexual assault is more likely to occur following separation/divorce from either spouses or cohabitors. Furthermore, this study provides more accurate data on the timing of assaults because it asked respondents to report whether their victimization occurred before, after, or both before and after the relationship was terminated. The principal investigators (Tjaden \& Thoennes, 2000, pp. 37-38) report that "most rapes

Table 1

Rates of forced sex in marriage by current marital status

\begin{tabular}{lcr}
\hline Marital status & \% reporting forced sex & $n$ \\
\hline Married & 3 & 224 \\
Separated/divorced & 25 & 76 \\
Cohabiting & 20 & 5 \\
Cohabiting, now separated & 23 & 13 \\
Widowed & 14 & 7 \\
\hline$P<.001$. & &
\end{tabular}


... perpetrated against women by intimates occur in the context of an ongoing rather than terminated relationship." At first glance, the VAWS data support this claim because only $6.3 \%$ of the total number of rape victims $(N=288)$ stated that they were raped after the relationship ended.

This figure is the only one that we could find in the survey literature that shows that women in ongoing relationships are more likely to be sexually assaulted than those who were separated/divorced. This is not surprising for several reasons directly relevant to the issue of defining separation/divorce sexual assault. First, VAWS researchers used a narrow definition of sexual assault restricted to what they define as "rape" and thus excluded a broad range of harmful behaviors experienced by many women. Note their five questions listed below ${ }^{5}$ (Tjaden \& Thoennes, 2000, p. 6):

- Has a man or boy ever made you have sex by using force or threatening to harm you or someone close to you? Just so there is no mistake, by sex we mean putting his penis in your vagina.

- Has anyone, male or female, ever made you have oral sex by using force or threat of force? Just so there is no mistake, by oral sex we mean that a man or boy put his penis in your mouth or someone, male or female, penetrated your vagina or anus with their mouth.

- Has anyone ever made you have anal sex by using force or threat of force? Just so there is no mistake, by anal sex we mean that a man or boy put his penis in your anus.

- Has anyone, male or female, ever put fingers or objects in your vagina or anus against your will or by using force or threats?

- Has anyone, male or female, ever attempted to make you have vaginal, oral, or anal sex against your will but intercourse or penetration did not occur (emphasis in original)?

Respondents who answered "yes" to the above questions were then asked whether their perpetrator was a current or ex-marital partner, a male or female live-in partner, a relative, "someone else they knew," or a stranger. In addition, women disclosing rape by an ex-partner were asked to further state which spouse/partner harmed them (e.g., first ex-husband, current male cohabiting partner) (Tjaden \& Thoennes, 2000).

The behaviorally specific questions used in the VAWS are important but excluded sexual assaults that occurred when victims were drunk or high, or when they were unable to give consent (Bachar \& Koss, 2001). Also excluded from the VAWS are "economic threats" that result in unwanted sexual relations and "blackmail rapes" that are said to be common in Australia (Russell, 1990). Note the following incident "Mrs. Brown" described to Russell (1990, p. 338). Just because there was no threat or actual use of force does not mean that her experience was not terrifying, and she clearly labels what her first husband did as rape:

The worst raping occasion was the morning I awoke in labour with my first child. The hospital I was booked into was a thirty-minute drive away, and this being the first time I

\footnotetext{
${ }^{5}$ These questions were adapted from those used by the National Victims Center and the Crime Victims Research and Treatment Center (1992).
} 
had undergone childbirth, I had no idea of how close I was to giving birth, or what was to happen to me next. I laboured at home for a few hours until perhaps 11:00 a.m., and then said to my ex-husband that I thought we'd better go to the hospital. The pains were acute and I was panicking that I would not be able to bear them. He looked at me, and said, "Oh, all right. But we'd better have a screw first, because it'll be a week before you're home again." I couldn't believe it, even of him. "Please, W., take me to the hospital," I begged as another contraction stormed across my body. "Not until we have a screw," he insisted. I wept, I cried, I pleaded, but he wouldn't budge. The pleading went on until midday, by which time I was frantic to get nursing help. He stood adamant with his arms crossed, a smirk on his face, and jiggling the car keys as a bribe. In the end I submitted. It took two minutes, then we dressed and drove to the hospital. The baby was born five hours later.

If the VAWS included behaviors like this, unwanted sex "out of a sense of obligation" (Bergen, 1996), sexual relations stemming from ex-partners threats of fighting for sole custody of children, and other acts that do not involve the use of or threats of force, the number of events that occurred after a relationship ended would have been higher. Of course, so would the number of events that occurred before separation/divorce, and other studies of marital rape (e.g., Russell, 1990) would have also generated much higher rates of sexual assault.

The fact that the VAWS was presented to respondents as a "crime study" also contributed to the marital status variations in sexual assault reported here. Crime surveys create a set of "demand characteristics" and unless female respondents clearly label their current or former partners' abusive acts as criminal in their own mind (and many women do not do so), they tend not to report them (Koss, 1996; Schwartz, 2000; Straus, 1998). In fact, close to $83 \%$ of marital violence incidents reported in surveys of family interactions are not reported in contexts where the research emphasis is on criminal assault and victimization (Mihalic \& Elliot, 1997).

Can only couples that live apart be considered separated/divorced? Many surveys of marital rape such as the VAWS and Finkelhor and Yllo's (1985), as well as surveys of nonsexual types of woman abuse, seem to define separation/divorce this way. This approach is highly problematic because it neglects assaults after women's decisions and/or attempts to leave while they are locked in relationships (Mahoney, 1991; Ptacek, 1999). Many men have a "fanatical determination" to not let their spouses/live-in partners go and if their sexual assaults on their wives/lovers' attempts to seek autonomy were recorded (Russell, 1990), the VAWS and other studies that neglected violence used to keep women in destructive, patriarchal relationships would have uncovered alarmingly higher rates of separation/divorce sexual assault. In fairness to VAWS researchers Tjaden and Thoennes (2000, p. 38), they acknowledge the above issue and call for more research on this and other issues related to separation/divorce and woman abuse.

In summary, the study of separation/divorce sexual assault is in, to say the least, a state of infancy, and thus much more careful attention needs to be paid to the issue of defining both sexual assault and separation/divorce. For reasons described here and elsewhere, rather than 
relying on narrow definitions of these problems, it is necessary to closely listen to women's voices. As Mahoney (1991, p. 41), one of the leading experts on separation assault, correctly points out, listening to women's stories "may be the only way to describe a complex reality for which we have few names." Listening to women's voices may also help researchers overcome or minimize the methodological problems identified in subsequent sections of this paper.

\subsection{Prevalence rates and risk factors}

Data on the prevalence of separation/divorce sexual assault may not be plentiful, but the limited amount that is available shows that just before, during, and after terminating a relationship with a spouse/cohabitor are risky times. For example:

- Eight percent of the wife rape survivors in Russell's (1990) were assaulted after their marriages ended, and $7 \%$ were raped just before separation.

- Seventeen percent of the divorced women interviewed by Kurz (1995) reported that their ex-husbands forced them to have sex.

- Twenty percent of the 40 wife-rape survivors interviewed by Bergen (1996) were raped after separation/divorce.

- Two thirds of the women in Finkelhor and Yllo's (1985) interview sample $(N=50)$ were raped in the last days of a relationship, either after previous separations, or when they were trying to leave a relationship.

The lowest prevalence rate uncovered yet is the VAWS (6.3\%) figure discussed previously. This estimate and those listed above would be higher if the definition of sexual assault used was broader and common-law relationship breakups were carefully examined. Consider, too, that these studies were specifically designed to study marital rape and thus the rates of separation/divorce sexual assault would have also increased if this harm was given a higher priority and more specific questions about separation/divorce sexual assault were asked.

Would researchers obtain similar, lower, or higher estimates if they surveyed or interviewed men? This is an empirical question that can only be answered empirically. So far, all of the data on separation/divorce sexual assault are derived from women. Typically, female victims/survivors, regardless of what type of relationship they have or have had, report higher levels of victimization than male accounts of offending (DeKeseredy \& Schwartz, 1998). Thus, some could assert that male perpetration prevalence rates would undoubtedly be lower, which could have a negative impact on service delivery to survivors. As argued by several researchers, if government officials are led by low prevalence figures to believe that separation/divorce sexual assault and/or other forms of woman abuse are minor problems, they are not likely to contribute sufficient resources to curb these harms (DeKeseredy, 2000; Smith, 1994).

Regardless of whether one studies men or women or both, there is always a danger that one's findings will be misused and/or misinterpreted. Furthermore, in a current political economic climate characterized by a rabid antifeminist backlash (DeKeseredy \& Schwartz, 
2003; Hammer, 2002), feminist scholars will consistently face resistance to their work on male-to-female violence and other major symptoms of gender inequality no matter who participates in their research. However, excluding men can exacerbate this backlash. For example, looking only at victims rather than the perpetrators can be interpreted as blaming women for their ex-partners' assaults (Mahoney, Williams, \& West, 2001). Research that examines how victims differ from those who are not victimized suggests that there is something "wrong" with those who are sexually abused by men (Bograd, 1988). For example, what would it tell us if we happened to find that abused women are less intelligent than their partners? Do less intelligent or more intelligent women deserve to be sexually assaulted?

Another reason to include men is that sexual assault, like other types of woman abuse, is best understood by examining the characteristics of men rather than women (Mahoney et al., 2001). Note that previous research on woman abuse in marriage/cohabitation (e.g., Smith, 1990a) and in-depth reviews of the extant literature reveal that focusing on victims' characteristics is futile. For example, Hotaling and Sugarman (1986) found only one variable out of 42 characteristics allegedly related to wife-victims that consistently discriminated between abused and nonabused women. This finding is consistent with the argument that any woman is a possible object of violence. What differs is not the woman, but the man. If the man is sexually abusive, he will victimize any woman with whom he lives with or has lived with (DeKeseredy \& Schwartz, 1998).

Research on men is required because, as Scully (1990, p. 4) reminds us, women cannot accurately reveal the reasons why men rape them because "they don't share the reality of sexually violent men. Such insight is acquired through invading and critically examining the social constructions of men who rape." Moreover, the farther one is from the source of harm such as sexual assault, the more likely the information is to be biased (Mahoney \& Williams, 1998). Consider, too, that men's abuse of women is male behavior and thus "more fruitful efforts" to explain it should focus on men (Hotaling \& Sugarman, 1986).

This is not to say, however, that we cannot learn much about the risk factors associated with separation/divorce sexual assault by asking women questions about the men who harmed them. In fact, all of the marital rape research conducted so far has elicited data from victims on the characteristics of perpetrators, and this approach has identified key risk factors such as men's adherence to the ideology of familial patriarchy (e.g., male control and domination in domestic or intimate settings). ${ }^{6}$ For example, in the course of describing a sexually abusive event to Russell (1990, p. 52), one woman said, "It was more like a wrestling match. "No, I don't want to." "Yes, you are going to do it." I ended up with bruises. "I'm your husband, you have to," he said."

Another area in need of additional research is separation/divorce sexual assault in rural areas. Almost all of the studies reviewed here, regardless of whether they are qualitative or quantitative, were conducted in urban areas, such as Boston and San Francisco. This is in part because it is easier to recruit a sample of urban dwellers. It is also due partly to the

\footnotetext{
${ }^{6}$ See Mahoney and Williams (1998) for a review of the research on the characteristics of male offenders.
} 
widespread belief that rural contexts are "idyllic and tranquil" centers of social activity (Websdale, 1998). However, nothing can be further from the truth. For example, Bachman (1992) found that women in nonmetropolitan areas were more likely to report having been raped by a relative or acquaintance than women living in metropolitan areas. Furthermore, Websdale (1998) found that half of 50 battered women he interviewed in rural Kentucky were forcibly raped by their partners. It is unclear from reading his study the number of respondents who were sexually abused during and after separation/divorce; but, it is fair to conclude that many are from reading his ethnographic account of the terrifying symptoms of "rural patriarchy."

Assumptions, though, are not reliable data. Hence, a carefully crafted study in a rural area is much needed. Hopefully, funded by the National Institute of Justice, DeKeseredy's (2002) exploratory study of separation/divorce sexual assault in rural Ohio will shed more light on a major social problem that is exacerbated by women's isolation. For example, many abused women live far away from neighbors, other agents of informal social control, social service providers, and criminal justice officials (Fletcher, Lunn, \& Reith, 1996; Mahoney et al., 2001). It should also be noted that Websdale's (1998) respondents told him that their abusers' assaults "feed off of" their partners' isolation. In addition, they often use tactics such as destroying their current or ex-wives' cars, which are much needed in rural locations due to the absence of public transportation. Consider what happened to "Barbara." She told Websdale that her ex-husband did not want her to have a car so that she would have to stay with him. In an attempt to get her back, he set her car on fire.

Obviously, there are many other groups of men and women who need to be included in future research, such as those who are immigrants, living in public housing, have mental disabilities, and so on. Furthermore, the review of the literature covered here reveals a major need for small- and large-scale representative sample surveys. There is also a conspicuous absence of theoretical work, which is just as important as empirical contributions to the field.

\section{Theoretical contributions}

Why do men sexually assault partners who want to leave or who have left them? Given the dearth of data on the motivations of men who engage in separation/divorce sexual assault, it is not surprising that there have been no theories specifically developed to answer this question. Even the marital rape literature can be defined as essentially atheoretical because it is restricted to either presenting women's opinions about why their partners assaulted them or to constructing typologies based on the information provided by female respondents (Mahoney \& Williams, 1998). For example, Finkelhor and Yllo (1985) identified three types of rape: battering rape, force-only rape, and obsessive rape. Since this and other typologies of marital rape (e.g., Bergen, 1996; Russell, 1990) have been reviewed elsewhere (see Mahoney \& Williams, 1998), it is beyond the scope of this paper to repeat these summaries here.

The above observations should not be construed as an all-out indictment of this limited theoretical work. Indeed, marital rape researchers have identified several important risk 


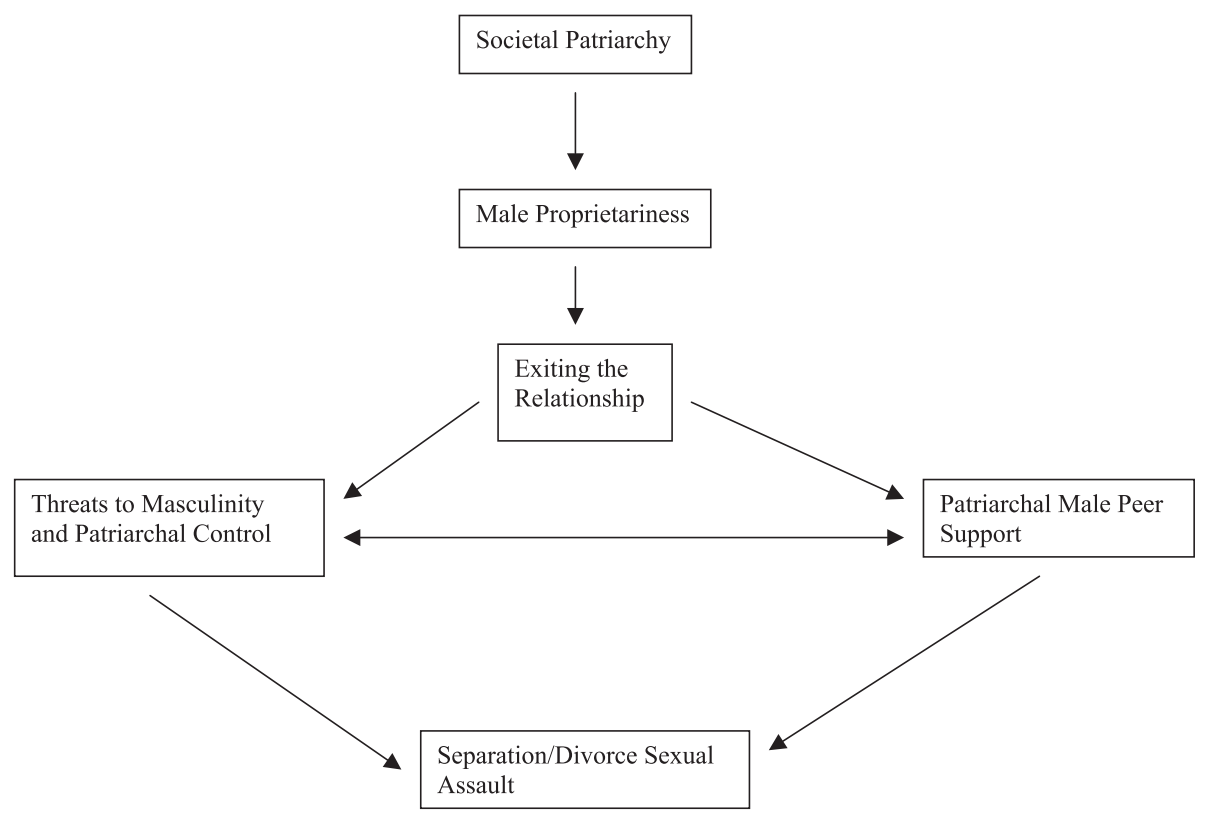

Fig. 1. A feminist/male peer support model of sexual assault during and after separation/divorce.

factors (e.g., power, control, an adherence to the ideology of familial patriarchy), which is an important step toward constructing and testing theories of separation/divorce sexual assault, as well as other variants of woman abuse (Jasinski, 2001). In fact, some of the determinants mentioned by participants in marital rape studies done by Bergen (1996), Russell (1990), and others (e.g., Finkelhor \& Yllo, 1985) are included in the theoretical model described in Fig. 1.

\section{New directions in research and theory}

\subsection{Suggestions for empirical work}

The first step is to develop quantitative and qualitative studies specifically crafted to answer questions similar to those guiding DeKeseredy's (2002) exploratory rural project. Below are some examples of the questions he is trying to answer using semistructured interview data provided by 150 women:

- Are separation/divorce sexual assaults more frequent and/or severe during certain stages of exiting a marriage or cohabiting relationship?

- Are women who try to exit or who have exited cohabiting relationships more likely to be sexually assaulted than women who try to leave or who have left their marital partners?

- Are survivors of separation/divorce sexual assault also victims of other forms of woman abuse, or is sexual assault the only type of abuse they experience? 
- Is separation/divorce sexual assault multidimensional in nature? For example, do survivors of estrangement sexual assault, like survivors of marital rape, experience different types of unwanted sexual activity, such as those identified in Finkelhor and Yllo's (1985) typology?

- What are the psychological, physical, economic, and other outcomes of separation/divorce sexual assault?

- Based on the survivors' perspectives, what types of social support and intervention are most effective?

Of course, as stated previously, studies of men and the factors that motivate them to sexually assault women are much needed. And, populations that typically receive little attention in woman abuse research warrant much more empirical scrutiny, such as immigrants and rural residents. Again, the definitions of separation/divorce that guide the empirical work suggested here should be broadened to include cohabitors and the definitions of sexual assault should be expanded to take into account a wider range of experiences than those examined in previous marital rape studies.

Many more suggestions for future research could be presented here, including the use of multiple measures of sexual assault (DeKeseredy, 2002; Mahoney \& Williams, 1998; Smith, 1994). However, no matter what research methods are being considered, the safety of female participants must be the overriding concern. For example, many abusive men open their partners' mail, monitor their phone calls, try to prevent them from seeing professionals (e.g., counselors), and engage in other types of "surveillance" (Campbell, 2000). Keep in mind too that some men kill women who are trying to leave them or who have left them. Researchers are also likely to come into contact with battered women who were sexually assaulted (Frieze, 1983) and they are at much higher risk of being murdered by male partners than battered women who have not been sexually assaulted (Campbell, 1981; Russell, 1990). Thus, conducting the research advocated here is a major responsibility and scholars should always use fail-safe ways of preventing threats to women's physical, psychological, and economic well-being. ${ }^{7}$

\subsection{New directions in theoretical work}

Hopefully, future theoretical work on separation/divorce sexual assault will not be limited to simply identifying risk factors and/or constructing typologies. When thinking about theory, a good place to start is found in the theoretical literature on nonsexual forms of violence (e.g., beatings, homicide, etc.) that occur when women want to exit or have left a relationship. ${ }^{8}$ Central to all of this work is the role of patriarchal dominance and control, which is also a major theme in the marital sexual assault literature (Mahoney \& Williams, 1998). In her recent attempt to develop an integrated theory of marital rape, Rogness (2002) contends that macrolevel factors like societal patriarchy work together with microlevel forces such as patriarchal male peer support to influence men to rape their martial/cohabiting partners.

\footnotetext{
${ }^{7}$ See Campbell and Dienemann (2001) for examples of techniques of protecting female respondents' safety.

${ }^{8}$ See Hardesty (2002) for an in-depth review of this literature.
} 
Guided by her integrated theory and Jasinki's (2001) call for "acknowledging the existence of multiple risk factors" when doing theoretical work on woman abuse in general, we offer the model presented in Fig. 1. Societal patriarchy, "male proprietariness" (Wilson \& Daly, 1992), and patriarchal male peer support are the major components of this model and we will briefly discuss these and the other variables included in it.

Heavily informed by perspectives offered by DeKeseredy and Schwartz (1993, 2002), Ellis and DeKeseredy (1997), Rogness (2002), and Wilson and Daly (1992), our model situates separation/divorce within the larger context of societal patriarchy. North America is well known for being a continent characterized by gross gender inequity (Renzetti \& Curran, 2000). For example, in 33 U.S. states, under law, a man can be awarded conditional exemptions if he raped his wife (National Clearinghouse on Marital and Date Rape, 1998). Many more examples of patriarchal practices and discourses could easily be provided. Nevertheless, the most important point to consider is that a constant such as societal patriarchy cannot explain a variable such as changes in the frequency and severity of male sexual assaults on women who want to or who have left them (Ellis \& DeKeseredy, 1997). In other words, if we live in a patriarchal society that promotes male proprietariness, why, then, do some men sexually assault during or after the exiting process, whereas most others do not? For instance, data generated by a number of researchers using patriarchal ideology scales of one kind or another indicate that there are variations in male proprietariness (DeKeseredy \& Kelly, 1993; Smith, 1990b), which is "the tendency [of men] to think of women as sexual and reproductive "property" they can own and exchange" (Wilson \& Daly, 1992, p. 85). Proprietariness refers to "not just the emotional force of [the male's] own feelings of entitlement but to a more pervasive attitude [of ownership and control] toward social relationships [with intimate female partners]" (p. 85).

Many women resist or eventually will resist their spouse/cohabiting partners' proprietariness in a variety of ways, such as arguing, protesting, and fighting back if they have been abused (Bergen, 1996; Ellis \& DeKeseredy, 1997; Sev'er, 2002; Websdale, 1998). There are also many women, although the precise number is unknown, who defy men's control by exiting or trying to exit a relationship and this may involve emotional separation, obtaining a separate residence, and/or starting or completing a legal separation/divorce. Emotional separation, a major predictor of a permanent end to a relationship, is defined as a woman's denial or restriction of sexual relations and other intimate exchanges. ${ }^{9}$ Emotionally exiting a relationship can be just as dangerous as physically or legally exiting one because it, too, increases the likelihood of male violence and sexual abuse (Kayser, 1993; Kirkwood, 1993; Markman \& Notarious, 1994; Russell, 1990).

Regardless of how a woman does it, her attempt to exit or her successful departure from a sexist relationship challenges male proprietariness, but exiting alone, like single factors, cannot account for sexual assault. For example, many abusive patriarchal men have male friends with similar beliefs and values and these peers reinforce the notion that women's exiting is a threat to a man's masculinity (DeKeseredy \& Schwartz, 2002). Furthermore,

\footnotetext{
9 This is a modified version of Ellis and DeKeseredy's (1997) definition of emotional separation.
} 
many members of patriarchal peer groups view wife beating, rape, and other forms of maleto-female victimization as legitimate and effective means of repairing "damaged patriarchal masculinity" (Messerschmidt, 1993; Raphael, 2001). Not only do these men verbally and publicly state that sexual assault and other forms of abuse are legitimate means of maintaining patriarchal authority and control, they also serve as role models because many of them physically, sexually, and psychologically harm their own intimate partners (DeKeseredy \& Schwartz, 2002).

In short, patriarchal male peer support contributes to the perception of damaged masculinity and motivates sexually abusive men to "lash out against the women ... they can no longer control" (Bourgois, 1995, p. 214). Another point to consider is that if a patriarchal man's peers see him as a failure with women because his partner wants to leave or has left him, he is likely to be ridiculed because he "can't control his woman." Hence, like many college men who rape women, he is likely to sexually assault her to regain status among his peers. Similar to other men who rape female strangers, acquaintances, or dates, the sexual assaults committed by men during or after the process of separation/divorce may have much more to do with their need to sustain their status among their peers than either a need to satisfy their sexual desires or a longing to regain a loving relationship (Godenzi, Schwartz, and DeKeseredy, 2001).

At this point in time, Fig. 1 serves as a building block for future theoretical construction. Obviously, there are other factors that contribute to separation/divorce sexual assault, such as male consumption of pornography (Russell, 1990, 1998), the contributions of formal and informal interventions (Ellis \& DeKeseredy, 1997), and everyday life-events stress (Hardesty, 2002). Still, of the very limited theoretical work done so far, our model seems the most promising. It is not a predictive model and it does not attempt to isolate specific perpetrators; however, several hypotheses derived from it could easily be tested using measures of male peer support developed by DeKeseredy (1988), Smith's (1990b) familial patriarchal ideology items, as well as several other measures. Hopefully, this and other theories will be evaluated in the near future using both quantitative and qualitative techniques. The latter are just as important as the former because men are exposed to a wide range of discourses and practices. Thus, to accurately identify and explain how they translate into separation/divorce sexual assault, it is necessary for researchers to "merge into" all-male cultures (Ellen, 1984). Building theories of any type of separation/divorce should also be "grounded in women's lived experiences," and so far the social scientific research community has not paid much attention to what women who have been victimized by those they have left or want to leave have to say (Hardesty, 2002, p. 618).

\section{Conclusions}

It has often been said that the "marriage license is a hitting license" and there is much empirical support for this claim (Straus, Gelles, \& Steinmetz, 1981). We also know that many women are raped by their husbands. For example, $14 \%$ of the women who participated in Russell's (1990) representative sample survey were harmed by this "intimate intrusion" 
(Stanko, 1985). Unfortunately, leaving a patriarchal "house of horrors" does not necessarily reduce women's risk of being victims of nonlethal physical violence or homicide (Sev'er, 2002). In fact, as noted at the start of this paper, exiting can significantly increase the risk of experiencing "deadly deeds" (Silverman \& Kennedy, 1993).

Based on a small number of studies, we also know that exiting a marital/cohabiting relationship or trying to exit increases women's chances of being sexually assaulted, especially if they are connected to patriarchal men. However, there is still much that we do not know about the problem of separation/divorce sexual assault. For example, there is a need for more reliable prevalence estimates and more empirical attention needs to be paid to cohabitation and to male perpetrators. Much more theoretical work is also necessary to advance a better understanding of sexual assault during emotional separation and other stages of exiting. A key objective of this paper is to encourage more research and theory in the field and we are optimistic that this will happen in the near future. The fact that the National Institute of Justice recently gave Walter DeKeseredy a grant to conduct an exploratory study is one sign that the research community and the federal government are beginning to recognize the need for more knowledge.

In addition to advancing social scientific understanding of a form of woman abuse that has not garnered much attention from the media, the scientific community, nor the criminal justice system, researchers should be equally concerned with generating policy-relevant data that can be used to tailor more effective prevention, control, and social support services for a group of women who continue to suffer in silence. Again, too often separation/divorce does not end sexual assault, and thus it is necessary to develop policies and practices that meet the unique needs of women who are terrorized by men who will not let them leave and men who they have left. If, as Bergen (1996) found, victims of marital rape do not receive proper assistance, we can only assume that victims of separation/divorce sexual assault are given even less.

\section{Acknowledgements}

This paper was presented at the 2002 annual meeting of the American Society of Criminology, Chicago. Some of the research reported here was supported by National Institute of Justice grant 2002-WG-BX-0004. Arguments presented in this paper are those of the authors and do not necessarily represent the official position or policies of the U.S. Department of Justice. The authors thank Bernard Auchter, Karen Bachar, Raquel Bergen, Katharine Darke, Bonnie Fisher, Mary Koss, Carolyn Joseph, and Claire Renzetti for their input.

\section{References}

Arendell, T. (1995). Fathers and divorce. Thousand Oaks, CA: Sage.

Bachar, K., \& Koss, M.P. (2001). From prevalence to prevention: Closing the gap between what we know about rape and what we do. In: C.M. Renzetti, J.L. Edleson, \& R.K. Bergen (Eds.), Sourcebook on violence against women (pp. 117-142). Thousand Oaks, CA: Sage. 
Bachman, R. (1992). Crime in nonmetropolitan America: A national accounting of trends, incidence rates and idiosyncratic vulnerabilities. Rural Sociology, 57, 546-560.

Bachman, R., \& Saltzman, L.E. (1995). Violence against women: Estimates from the redesigned National Crime Victimization Survey. Rockville, MD: U.S. Department of Justice.

Bergen, R.K. (1996). Wife rape: Understanding the response of survivors and service providers. Thousand Oaks, CA: Sage.

Bograd, M. (1988). Feminist perspectives on wife abuse: An introduction. In K. Yllo, \& M. Bograd (Eds.), Feminist perspectives on wife abuse (pp. 11-26). Newbury Park, CA: Sage.

Bourgois, P. (1995). In search of respect: Selling crack in El Barrio. New York: Cambridge University Press.

Campbell, J.C. (1981). Misogyny and homicide of women. Advances in Nursing Science, 3.

Campbell, J.C. (1989). Women's response to sexual abuse in intimate relationships. Health Care for Women International, 10, 335-346.

Campbell, J.C. (2000). Promise and perils of surveillance in addressing violence against women. Violence Against Women, 6, 705-727.

Campbell, J.C., \& Dienemann, J.D. (2001). Ethical issues in research on violence against women. In C.M. Renzetti, J.L. Edleson, \& R.K. Bergen (Eds.), Sourcebook on violence against women (pp. 57-72). Thousand Oaks, CA: Sage.

DeKeseredy, W.S. (1988). Woman abuse in dating relationships: The role of male peer support. Toronto: Canadian Scholars' Press.

DeKeseredy, W.S. (2000). Current controversies on defining nonlethal violence against women in intimate heterosexual relationships: Empirical implications. Violence Against Women, 6, 728-746.

DeKeseredy, W.S. (2002). Sexual assault during and after separation/divorce: An exploratory study. (Proposal funded by National Institute of Justice Grant WG BX 0004). Athens, OH: Ohio University.

DeKeseredy, W.S., \& Hinch, R. (1991). Woman abuse: Sociological perspectives. Toronto: Thompson Educational Publishing.

DeKeseredy, W.S., \& Kelly, K. (1993). Woman abuse in university and college dating relationships: The contribution of the ideology of familial patriarchy. Journal of Human Justice, 4, 25-52.

DeKeseredy, W.S., \& MacLeod, L. (1997). Woman abuse: A sociological story. Toronto: Harcourt Brace.

DeKeseredy, W.S., \& Schwartz, M.D. (1993). Male peer support and woman abuse: An expansion of DeKeseredy's model. Sociological Spectrum, 13, 393-413.

DeKeseredy, W.S., \& Schwartz, M.D. (1998). Woman abuse on campus: Results from the Canadian national survey. Thousand Oaks, CA: Sage.

DeKeseredy, W.S., \& Schwartz, M.D. (2002). Theorizing public housing woman abuse as a function of economic exclusion and male peer support. Women's Health and Urban Life, 1, 26-45.

DeKeseredy, W.S., \& Schwartz, M.D. (2003). Backlash and whiplash: A critique of Statistics Canada's 1999 General Social Survey on Victimization. Online Journal of Justice Studies ([On-line]. Available: http://ojjs. icaap.org).

Dexter, L.A. (1958). A note on the selective inattention in social science. Social Problems, 6, 176-182.

Ellen, R.F. (1984). Ethnographic research. New York: Academic Press.

Ellis, D. (1987). The wrong stuff: An introduction to the sociological study of deviance. Toronto: Collier Macmillan.

Ellis, D. (1992). Woman abuse among separated and divorced women: The relevance of social support. In E.C. Viano (Ed.), Intimate violence: Interdisciplinary perspectives (pp. 177-188). Bristol: Taylor \& Francis.

Ellis, D., \& DeKeseredy, W.S. (1989). Marital status and woman abuse: The DAD model. International Journal of Sociology of the Family, 19, 67-87.

Ellis, D., \& DeKeseredy, W.S. (1997). Rethinking estrangement, interventions, and intimate femicide. Violence Against Women, 3, 590-609.

Ellis, D., \& Stuckless, N. (1996). Mediating and negotiating marital conflicts. Thousand Oaks, CA: Sage.

Finkelhor, D., \& Yllo, K. (1985). License to rape: Sexual abuse of wives. New York: Holt, Rinehart and Winston.

Fletcher, S., Lunn, D., \& Reith, L. (1996). Fear on the farm: Rural women take action against domestic violence. Women and Environments, 38, 27-29. 
Fleury, R.E., Sullivan, C.M., \& Bybee, D.I. (2000). When ending the relationship does not end the violence: Women's experiences of violence by former partners. Violence Against Women, 6, 1363-1383.

Frieze, I. (1983). Investigating the causes and consequences of marital rape. Signs: Journal of Women in Culture and Society, 8, 532-553.

Gartner, R., Dawson, M., \& Crawford, M. (2001). Women killing: Intimate femicide in Ontario, 1874-1994. In D.E.H. Russell, \& R.A. Harmes (Eds.), Femicide in global perspective (pp. 147-165). New York: Teachers College Press.

Godenzi, A., Schwartz, M.D., \& DeKeseredy, W.S. (2001). Toward a gendered social bond/male peer support theory of woman abuse. Critical Criminology, 10, 1-16.

Hammer, R. (2002). Antifeminism and family terrorism: A critical feminist perspective. Lanham, MD: Roman \& Littlefield.

Hardesty, J.L. (2002). Separation assault in the context of postdivorce parenting: An integrative review of the literature. Violence Against Women, 8, 597-621.

Hotaling, G., \& Sugarman, D. (1986). An analysis of risk markers and husband-to-wife violence. The current state of knowledge. Violence and Victims, 1, 102-124.

Jasinski, J.L. (2001). Theoretical explanations for violence against women. In C.M. Renzetti, J.L. Edleson, \& R.K. Bergen (Eds.), Sourcebook on violence against women (pp. 5-22).

Johnson, H., \& Sacco, V.F. (1995). Researching violence against women: Statistics Canada's national survey. Canadian Journal of Criminology, 37, 281-304.

Kayser, K. (1993). When love dies: The power of marital disaffection. Boston: Beacon.

Kennedy, L.W., \& Dutton, D.G. (1989). The incidence of wife assault in Alberta. Canadian Journal of Behavioural Science, 21, 40-54.

Kirkwood, C. (1993). Leaving abusive partners. Newbury Park, CA: Sage.

Koss, M.P. (1996). The measurement of rape victimization in crime surveys. Criminal Justice and Behavior, 23, 55-69.

Kurz, D. (1995). For richer or poorer: Mothers confront divorce. New York: Routledge.

Mahoney, M.R. (1991). Legal issues of battered women: Redefining the issue of separation. Michigan Law Review, 90, 1-94.

Mahoney, P., \& Williams, L.M. (1998). Sexual assault in marriage: Prevalence, consequences, and treatment of wife rape. In J.L. Jasinski, \& L.M. Williams (Eds.), Partner violence: A comprehensive review of 20 years of research (pp. 113-162). Thousand Oaks, CA: Sage.

Mahoney, P., Williams, L.M., \& West, C.M. (2001). Violence against women by intimate relationship partners. In C.M. Renzetti, J.L. Edleson, \& R.K. Bergen (Eds.), Sourcebook on violence against women (pp. 143-178). Thousand Oaks, CA: Sage.

Markman, H., \& Notarious, C. (1994). We can work it out: Making sense of marital conflict. Boulder, CO: Rockwell.

Messerschmidt, J.W. (1993). Masculinities and crime: Critique and reconceptualization. Lanham, MD: Roman \& Littlefield.

Mihalic, S.W., \& Elliot, D. (1997). If violence is domestic, does it really count? Journal of Family Violence, 12, $293-311$.

National Clearinghouse on Marital and Date Rape (1998). State law chart. Berkeley, CA: Author.

National Victims Center and the Crime Victims Research and Treatment Center (1992). Rape in America: A report to the nation. Arlington, VA: Author.

Pagelow, M.D. (1993). Justice for victims of spouse abuse in divorce and child custody cases. Violence and Victims, 8, 69-80.

Peacock, P. (1998). Marital rape. In R.K. Bergen (Ed.), Issues in intimate violence (pp. 225-236). Thousand Oaks, CA: Sage.

Ptacek, J. (1999). Battered women in the courtroom: The power of judicial responses. Boston: Northeastern University Press.

Raphael, J. (2001). Public housing and domestic violence. Violence Against Women, 7, 699-706. 
Renzetti, C.M., \& Curran, D.J. (2000). Living sociology (2nd ed.). Boston: Allyn \& Bacon.

Renzetti, C.M, Edleson, J.L., \& Bergen, R.K. (2001). Theoretical and methodological issues in researching violence against women. In C.M. Renzetti, J.L. Edleson, \& R.K. Bergen (Eds.), Sourcebook on violence against women (pp. 1-3). Thousand Oaks, CA: Sage.

Rodgers, K. (1994). Wife assault: The findings of a national survey. Ottawa: Canadian Centre for Justice Statistics.

Rogness, M., (2002). Toward an integrated male peer support model of marital rape in the United States. MA thesis, Ohio University, Department of Sociology and Anthropology, Athens.

Russell, D.E.H. (1990). Rape in marriage. New York: Macmillan Press.

Russell, D.E.H. (1998). Dangerous relationships: Pornography, misogyny, and rape. Thousand Oaks, CA: Sage.

Schwartz, M.D. (2000). Methodological issues in the use of survey data for measuring and characterizing violence against women. Violence Against Women, 6, 815-838.

Scully, D. (1990). Understanding sexual violence: A study of convicted rapists. Boston: Unwin Hyman.

Sev'er, A. (2002). Fleeing the house of horrors: Women who have left abusive partners. Toronto: University of Toronto Press.

Silverman, R., \& Kennedy, L. (1993). Deadly deeds: Murder in Canada. Scarborough, ON, Canada: Nelson.

Smith, M.D. (1990a). Sociodemographic risk factors in wife abuse: Results from a survey of Toronto women. Canadian Journal of Sociology, 15, 39-58.

Smith, M.D. (1990b). Patriarchal ideology and wife beating: A test of a feminist hypothesis. Violence and Victims, 5, 257-273.

Smith, M.D. (1994). Enhancing the quality of survey data on violence against women: A feminist approach. Gender and Society, 8, 109-127.

Stanko, E.A. (1985). Intimate intrusions: Women's experiences of male violence. London: Routledge.

Statistics Canada (1990). Conjugal violence against women. Ottawa: Author.

Straus, M.A. (1998). The controversy over domestic violence by women: A methodological, theoretical, and sociology of science analysis. Paper presented at the Claremont Symposium on Applied Social Psychology on Violence in Intimate Relationships, Claremont, CA, February.

Straus, M.A., Gelles, R.J., \& Steinmetz, S.K. (1981). Behind closed doors: Violence in the American family. New York: Anchor.

Tjaden, P., \& Thoennes, N. (2000). Extent, nature, and consequences of intimate partner violence: Findings from the National Violence Against Women Survey. Washington, DC: U.S. Department of Justice.

Websdale, N. (1998). Rural woman battering and the justice system: An ethnography. Thousand Oaks, CA: Sage.

Wilson, M., \& Daly, M. (1992). Til death do us part. In J. Radford, \& D.E.H. Russell (Eds.), Femicide: The politics of women killing (pp. 83-98). New York: Twayne.

Wilson, M., \& Daly, M. (1994). Spousal homicide. Ottawa: Canadian Centre for Justice Statistics. 